\title{
The role of "trust" in building customer loyalty in insurance sector- A study
}

\author{
${ }^{1}$ Kassegne Damtew, Ph.D research scholar, ${ }^{2}$, Dr.Venkat Pagidimarri, Professor \\ ${ }^{I}$ Osmania University, Department of Business Management. \\ ${ }^{2}$ Department of Business Management, Osmsnia university, Hyderabad
}

\begin{abstract}
Numerous policyholders are indispensable for insurers for their survive and prosperity in today's competitive business environment. Customers can purchase different and more policies from the same providers and renewal their agreements before expiry date if they have trust on their respective providers Insurers provide to customers promises so that trust is more essential for insurance sectors. "Trust is particularly important within service industries because of the abstract nature of most service products"(Coulter and Coulter3,2003). It is observed that Ethiopian insurance industry faces a challenge of high customer churn rate. Customers are lapsed increasingly from the existing providers in which the defect customer damages the company by spreading company bad experiences to others and decreasing income of the company as they may not renewal one or two or three of the policies.

An empirical insurance survey (Ernst \& Young 2012) made on Indian life insurance shows that $33 \%$ of customers explained price is a factor in their insurance provider selection, company trustworthiness (69\%), customer service (43\%) and convenience (38\%). This means that trustworthiness is uniquely essential in insurance sector as insurance company is selling promises. Thus, this study aims at to analyze the role of trust in building customer loyalty in the insurance sector. In order to achieve this objective, non-experimental study was designed for this study and to elicit policyholders' attitude, structured questionnaires were designed, and then analysis is made and results are explained. Pearson correlation and Regression analysis were used to examine the relationships between customer trust and customer loyalty using SPSS 16.0 and the result of the study indicates that customer trust has direct and positive relationships to customer loyalty.
\end{abstract}

Key words: Customer trust, customer loyalty, insurance, insurers, customers (policyholders)

\section{Introduction}

Insurers need large number of policyholders for their survival and prosperity. A policyholder may hold several contracts with the same company, covering different risks. This means insurance agreements are written for every type of risk covered. A customer and insurer relationship is a very special type of relationship as it involves long-term commitment. The globalization of competition, saturation of markets, and development of information technology have enhanced insurers' awareness and created a situation where long-term success can be achieved by building customer loyalty. It is observed that companies need to keep their current customers rather than devoting additional resources to chase potential new customers. Oromia insurance company (2010/11) put the code value that delineates the importance of customers and trust for the company so as the company should have to pledge as:

"Customers are our lifeblood

We are committed to service excellence

We act with honesty, integrity and loyalty" (p.1).

The company core values presented above disclose the following.

1. Customers are means for company survival

2. Providing efficient service for customers.

3. Be honesty and win customer trust

4. And maintain customer loyalty

The premise is that when customers are loyal they exhibit more nonrandom purchase continuously; they devote to encourage their families friends and acquaintances in recommending company products. Researchers pointed out that trust in insurance providers enhance customer loyalty. Morgan and Hunt (1994) posit that trust is a major determinant of relationship commitment: brand trust leads to brand loyalty because trust creates exchange relationships that are highly valued. Furthermore, Zikmund et at., (2003) and Spekman (1998) call trust a corner stone of the strategic partnership. In view of this, the study attempts to examine the role of trust in building customer loyalty in the insurance sector of Ethiopia and the study is presented as follows. 


\section{Statement of the problem}

Competition in the global insurance sector is becoming fierce due to mushrooming of insurance companies and development of information technology which enhance customer awareness. Despite of favorable condition for insurance development in Ethiopia, customers' defections are high in the insurance sector. Interview with Nile insurance marketing director shows, from 25,840 policyholders 3,997 (15\%) did not renewal their policies in 2010/11. According to Ethiopian Insurance Corporation Business Development and Risk Management Department Director interview response, from the total of (general and life) 69,731 policies $17,884(25.6 \%)$ were not renewed in 2011. This is supported by Jacada (2008) \& American satisfaction index that revealed (26\%) of insurance customers switch insurance providers.

The longer a customer stays with a company, the more that company is worth. Long term customers can purchase other policies more, take less of a company's time, are less sensitive to price, and bring in new customers. This means, insurance companies should give emphasis to retain customers and make them loyal to the company for survive and prosperity. But, customer retention becomes a challenge for Ethiopian insurers.

Thus, considering such challenges, this study is aimed at analyzing the role of trust in building customer loyalty in the insurance sector of Ethiopia. It is believed that the result of the study gives sidelights for insurers in order to mobilize resources in creating loyal customers in their respective companies. The overall objective of the study is delineated below.

\section{Objective of the Study}

The overall objective of the study is to analyze the role of customer trust in building customer loyalty in the insurance sector of Ethiopia and consequently the study has undertaken the following specific objectives.

\section{Specific Objectives}

1. To examine the relationship between customer trust on company employees and customer loyalty in the insurance sector.

2. To analyze the relationship between customer trust on company and customer loyalty in the insurance sector. Hence the following hypothesis is formulated in order to guide the research.

\section{Hypotheses}

Against the background of the research objectives and review of literature the following hypotheses were set to test statistically the objectives of the study:

$\mathbf{H o}_{1}$ : There is no significant relationship between customer trust on insurance company employees and customer loyalty in the insurance sector of Ethiopia.

$\mathbf{H}_{11}$ : There is significant relationship between customer trust on insurance company employees and customer loyalty in the insurance sector of Ethiopia

$\mathbf{H o}_{2}$ : There is no significant relationship between customer trust on insurance company and customer loyalty in the insurance sector of Ethiopia

$\mathbf{H 1}_{2}$ : There is no significant relationship between customer trust on insurance company and customer loyalty in the insurance sector of Ethiopia

Moreover, the significance of the study is described below.

\section{Significance of the study}

Ethiopian insurance industry currently faces challenges of lapsing customers which entails decline of premium. Genesy (2008) reveals that $31 \%$ of European non-life insurance has changed providers in five years. It is found that when a company retains just $5 \%$ or more of its customers, profit increase by $25 \%$ to $125 \%$ (Bowen \& Chen 2001). The more customers retain in the company, the more new customers rush into the company due to loyal customers playing the role of advocacy by initiating friends, relatives and acquaintances towards the company. Gnrnst \& Young Global Consumer Insurance Survey 2012, shows that on average, $38 \%$ of customers in India purchased more than one product from the same provider because they trusted the company. This implies customer trust in the company is a indispensable factor for insurance sector.

If customers are loyal they will retain in the company and purchase additional policies and renew policies. This leads to superior long-term financial performance. Therefore, to maintain customer loyalty in the insurance sector, the role of trust in building customer loyalty should be identified. An understanding of this construct and its influence on customer loyalty has practical implications for insurers, agents and brokers that can help them to deploy resources in order to enhance customer loyalty in their perspective company

\section{Review literatures}

Lovelock and Wirtz (2004, p.76) defined customer loyalty as: “A customer's willingness to continue patronizing a firm over the long term and recommending the firm's products and services to friends and 
associates". In addition to this, Heskett et al (1994) gave definition of customer loyalty as: Customer loyalty represents the repeat purchase, and referring the company to other customers.

To put in a nutshell, the definition of customer loyalty presented above, describe three points as:

1. Customer's willingness to continue patronizing a firm over the long term

2. Recommending the firm's products and services to friends and associates

3. Customer exhibits non-random repeat purchasing behavior from the same provider

As the definitions indicate a loyal customer is committed to continue long-term and renewal policies from the present provider. He /she continually making cross selling and extend the good reputation of company experience to other people.

"When a company consistently delivers superior value and wins customer loyalty, market share and revenues go up, and the cost of acquiring and serving customers goes down" (Rechheld 1993, p. 64). This means market share and revenues increase as a result of loyal customers who make repeat purchases and make referrals. The company's costs also decrease because less money is spent trying to lure in new customers. Nationwide Insurance study found that a $1 \%$ increase in customer retention increased annual premiums by $\$ 1$ million "(Insurance Technology, 2008). . Ernst \& Young (2012) conduct research on insurance sector of Japan and the findings showed that cross -selling is the key to boosting profitability of insurance company. According to this survey Trust in the provider is the main factor driving for repeat purchases.

\section{The relationship between Customer Trust and customer loyalty}

Trust is a concept studied in various disciplines and, as a result, there are different definitions of trust. A dictionary definition of trust: "A psychological state where a person accepts vulnerability based upon positive expectations of the intentions of another". Gefen et al (2003) define trust as: the willingness of a party to be vulnerable to the actions of another party based on the expectation that the other will perform a particular action important to the trustor, irrespective of the ability to monitor or control that other party.

When there is trust customers believe that the marketer is reliable and has integrity and a customer has confidence that the employee is honest, fair and responsible and his or her word can be relied on. Nobody expects a long-term relation with a partner that cannot be trusted. When there is trust in a relationship all parties believe that none will act opportunistically. Morgan and Hunt (1994) stated that trust exists only when one party has confidence in an exchange partner's reliability and integrity. They posit that trust is a major determinant of relationship commitment: brand trust leads to brand loyalty because trust creates exchange relationships that are highly valued. Zikmund et at., (2003) and Spekman (1998) call trust a corner stone of the strategic partnership.1998) call trust a corner stone of the strategic partnership.

\section{.Reasons why trust matters for insurance companies.}

Insurance is a promise to perform in future in return for a present monetary consideration. Such a promise is made in an environment when the customer is absolutely not sure whether the promise will be fulfilled if and when the need arises. Insurance is intangible product and uniquely depends on trust. Halliburton and Poenaru(2010) made interview with marketers unanimously and got response about the importance of customer trust as :

"For us, trust is the Holy Grail, its importance is 11 out of $10 \ldots$ we are saying to our customers, 'trust us with your future' "'(Marketing Manager Interview, Banking).

The main benefit of trust is customer loyalty, which in turn leads to a longer term relationship, and higher advocacy or word-of-mouth. Trust is more important for insurance company than any other type of business because insurance company is selling a promise. Insurance companies collect the premiums of the customer, manage the premiums, and disperse the risk to ensure they can pay off any losses. The signing of the insurance contract is based on trust, which means the customer is required to inform the actual condition to the insurance company for risk assessment and calculate the premiums, while the customer must clearly acknowledge the contents of the contract to make sure all benefits are acquired. Thus, "trust" is one key factor for success of the deal (Dwyer et al., 1987).

However, Insurance industry suffers from a general lack of trust (Christian, 2008). A customer survey on "trust in consumer relationship "which conducted in UK and US revealed that the overall customer trust in Banks is $(57 \%)$, in insurance provider is $(48 \%)$ and in mobile network operator is $(45 \%)$. The findings also illustrated drivers of customer trust as: reputation, past customer service, management policies, communications, services and trust in employees.

Similarly, Halliburton \& Poenaru (2010), made study on "the role of trust on consumer relationship" which showed that only (48\%) of UK and US consumers trust their insurance providers. And also the study suggests that "communication would have the greatest impact in terms of developing trust to build customer loyalty. Insurance providers can improve their relationships with customers by ensuring that every customer 
interaction is personalized and relevant to meet the needs of each individual. Creating a relationship and engendering customer loyalty that extends beyond the policy renewal must consistently be the top priority.

An empirical insurance survey (Ernst \& Young 2012) of Indian life insurance study shows that price is an important component of value, but it is not the only one in provider selection. Customers will also consider the service they have received and the trust they have in the provider. According to this survey in Indian insurance company, $33 \%$ of customers indicated that price is a factor in provider selection, company trustworthiness $(69 \%)$, customer service $(43 \%)$ and convenience $(38 \%)$.

Furthermore, $38 \%$ of customers who purchased more than one product from the same provider did so because they trusted the company (Ernst \& Young 2012). This means that trustworthiness is uniquely essential in insurance sector as insurance is selling promises. In building trust customers need to see things in the company as: company's capability to deliver on promises, company's fair treatment for customers, and honesty and authentic of company employees, management company as a whole.

Therefore, insurers need to, spend their energy delivering on what they promised to offer to customers. Goodman .N (2012) argued that people naturally prefer to hide mistakes, but insurers should be direct and open as much as possible. According to Goodman any sense of secrecy, concealment, or dishonesty will undermine the public's trust. This implies that when you make mistake, own up to it immediately, share what you're doing to correct it, and follow through. Lyle (2005) examined trust, satisfaction and loyalty in CRM: an application of justice theory and he confirmed that trust and loyalty are positively related. Thus, with increasing customer trust on company employees and insurers, customer loyalty is likely to enhanced.

Reichheld (1996), Morgan and Hunt (1994) suggest that brand trust leads to brand loyalty and commitment because trust creates exchange relationships that are highly valued. Trust towards insurance according to Gronroos (2001) depends not only on the laws, industry regulations and contracts but also on the professionalism of the other party. If a customer, for example, has entered into a long-term contract with a service provider, the customer trusts that the service provider will perform according to expectations. Therefore, customer trust has a positive influence on customer loyalty. The greater the customer trust is, the higher the customer loyalty becomes. Both customer trust in the employees and customer trust in the company are positively related to customer loyalty ( Sirdeshmukh \& et al., 2002).

Customer trust derives from beliefs about management policies such as principles, values, statements, contracts, regulations, and guarantees in which customers feel safe, assured, and comfortable about the prospect of depending on the businesses (Yousafzai et al. (2005). Although, the concept of customer trust is divergent, in this study trust is viewed as a set of trusting beliefs, in employees and insurance companies, captured as customer confidence in the quality and reliability of the services offered and complaint management process. So the study tries to measure customer trust from two approaches of customers trust on company employees and customer trust on the overall insurance companies. Thus, the conceptual model for this study is depicted below.

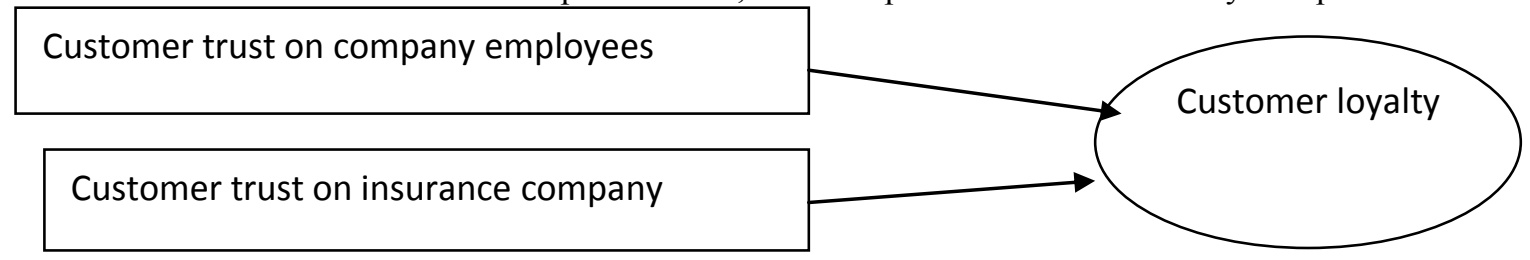

Figure 1: Conceptual model

\section{Research Design}

\section{Research Methodology}

The study aims at to determine solutions to problems of customer lapsing, so that the study focuses on policyholders' perceptions and attitude survey to identify the role of trust in building customer loyalty in insurance sector of Ethiopia. Based on the sample studies the study generalized the findings to the population. Therefore, a single cross -sectional descriptive study was used to obtain a picture of policyholders' opinions of their status of trust to their respective insurance companies. The survey was carried out in a natural field conditions and data collected pertaining to respondents' attitudes and perceptions . The survey items are statements on which respondents will be asked to indicate the extent of their agreement or disagreement, using five points, Likert-scale items. The data for this survey are derived from primary and secondary sources. The sources of data are depicted below.

\section{Research methods-Secondary and primary}

For the purpose of this research, secondary and survey data collection methods are used. Survey method is selected because a survey is a means of gathering information about a particular population by sampling some of its members. The primary data required for this study collected through structured 
questionnaires from sample respondents via enumerates for distribution and collection of questionnaires. The main source of data is policyholders of insurance companies in Addis Ababa, Ethiopia. The secondary data sources include: books, journals, reports, previous studies, and electronic sources relevant to the study. Secondary data contributed toward the formation of back ground information, analysis \& conclusion.

\section{Questionnaire Design}

The questionnaires to be used for this research are structured under three categories in order to measure attitudes of policyholders: Demographic, customer trust, and customer loyalty .The questions are designed in a manner so as to glean the maximum information from the respondents and taking minimum of their time. The questionnaires are adapted from previous researches used for collecting information about people's beliefs, attitudes, and behavior and designed for self-administered by the respondents in that to elicit genuine information; the respondents were assured of complete anonymity and confidentiality of responses .The respondents also told their participation is purely voluntary.

\section{Sample design}

The sample design and procedures for this study were done in five procedures as delineated below.

\section{Study population}

The population for this study is insurance company policyholders who are currently getting service from 15 insurance companies including the newly established one. Sample of companies and customers are taken from the population.

\section{Sampling unit}

Insurance business operates all over the country and it is overwhelming to conduct attitude survey of all policyholders in the country. Thus, the study of attitude survey focused on policyholders who get insurance service in Addis Ababa, capital city of Ethiopia.

\section{Sampling}

In assessing policyholders' attitude of trust towards the providers studying the whole population could not be done due to so many reasons. Thus, for this study sampling was appropriate methods and so that four companies needed to be taken as sample to conduct policyholders' attitude survey . Based on insurance companies licensed business area three companies from each category (Nonlife, Life \& Composite) using probability approach of simple random sampling were taken as sample of the study.

\section{Sampling technique}

Probability sampling was appropriate for this study rather than non probability sampling. Consequently, for this study in which its respondents are heterogeneous stratified random sampling is more appropriate as this is underpinned by Kothari (2011) "if a population from which a sample is to be drawn does not constitute a homogeneous group stratified sampling technique is generally applied in order to obtain representative sample"(p.62).

\section{Sample size}

According to Mahlotra (2008, pp. 368-369) "Sample size refers to the number of elements to be included in the study". Thus, the policyholders' attitude \& perception survey sample size is based on Nargundkar (2010) formula for sample size calculation. Based on this, the sample size required for the survey was 360 respondents for this study to conduct the attitude and perception survey of trust in insurance companies. The questionnaires were distributed for 360 respondents according to the short-list by enumerates and collected by enumerates but only $285(79 \%)$ questionnaires were found fit and taken for analysis.

\section{Validation of scales}

"Reliability is the property by which consistent results are achieved when we repeat the measurement of something. A questionnaire used on a similar population that produce similar results can be termed as reliable" ( Nargundka (2010, p. 62). Cronbach's Alpha is used as a testing instrument as it is the most used reliability test among researchers. The reliability of the instrument means that its results are characterized by repeativeness (Psarou and Zafiropoulos, 2004). Georg and Mallery provided the following rule of thumb for judging the acceptability of the internal consistency as cited in Prabhakar (2006:6).

Table 1: Rule of Thumb for Cronbach Alpha

\begin{tabular}{|l|l|l|l|}
\hline Rate & standard & Rate & Standard \\
\hline$\geq \mathbf{0 . 9}$ & Excellent & $\geq \mathbf{0 . 6}$ & Questionable \\
\hline$\geq \mathbf{0 . 8}$ & Good & $\geq \mathbf{0 . 5}$ & poor \\
\hline$\geq \mathbf{0 . 7}$ & Acceptable & $<\mathbf{0 . 5}$ & Unacceptable \\
\hline
\end{tabular}


Source: Georg and Mallery as cited in Prabhakar (2006:6)

\section{Reliability checking for variables}

The table below shows reliability statistics of: Customer trust on company employees, customer trust on company and customer loyalty.

Table 2: Reliability Statistics

\begin{tabular}{|r|r|}
\hline Cronbach's Alpha & N of Items \\
\hline
\end{tabular}

As presented in the above table, the reliability was reported as. 823 that is above the standard of .70 . This ensures variables have been measured the same construct generating the internal consistency.

\section{Statistical treatment used in data analysis}

In the process of converting data into useful information different types of analysis were employed using SPSS 16.0 and Amos 5.0 soft wares. The detail is illustrated below.

Table 3: Types of analysis \& Statistical tools used in the analysis

\begin{tabular}{|l|l|l|l|}
\hline $\begin{array}{l}\text { Types of analysis } \\
\text { applied }\end{array}$ & Statistical tools employed & $\begin{array}{l}\text { Software } \\
\text { used }\end{array}$ & Purpose of analysis \\
\hline Univariate & Descriptive statistics & SPSS & For obtaining information as required. \\
\hline Bivariate & Pearson correlation & SPSS & To know the degree of association between variables \\
\hline Multivariate & Regression & $\begin{array}{l}\text { SPSS } \\
\text { \&Amos }\end{array}$ & $\begin{array}{l}\text { To know the influence of customer trust on customer } \\
\text { loyaltyd }\end{array}$ \\
\hline
\end{tabular}

The table above shows the types of analysis, statistical tools employed and the purpose of analysis.

\section{Data Analysis and interpretation}

Analyzing relationships

The objective of the study is to examine the relationship between the independent variables and dependent variable (customer loyalty) in insurance sector of Ethiopia. These variables are customer trust in company employees and customer trust on the insurance company. Whether there is a relationship between these factors and customer loyalty Pearson correlation coefficient analysis was performed. The application of the correlation analysis is to measure the degree of association between variables. Here below is Hinkle et al (2003) rule of thumb for correlation analysis.

Rule of Thumb for Interpreting the Size of a Correlation Coefficient (Hinkle et al 2003)

\begin{tabular}{ll}
\multicolumn{1}{c}{ Size of Correlation } & \multicolumn{1}{c}{ Interpretation } \\
\hline .90 to $1.00(-.90$ to -1.00$)$ & Very high positive (negative) correlation \\
.70 to $.90(-.70$ to -.90$)$ & High positive (negative) strong \\
.50 to $.70(-.50$ to -.70$)$ & Moderate positive (negative) correlation \\
.30 to $.50(-.30$ to -.50$)$ & Low positive (negative) correlation \\
.1 to $.30(.00$ to -.30$)$ & Weak \\
0 & Zero indicating no relationships \\
\hline
\end{tabular}

\section{i. Null Hypotheses}

$\mathbf{H o}_{1}$ : There is no significant relationship between customer trust on company employees and customer loyalty in the insurance sector of Ethiopia.

$\mathrm{Ho}_{2}$ : There is no significant relationship between customer trust on company and customer loyalty in the insurance sector of Ethiopia

\section{ii. Findings and inferences made}

Table 4: Correlations Matrix between variables (Alpha .01

\begin{tabular}{|ll|r|r|r|}
\hline Customer trust on employees & Pearson Correlation & $\begin{array}{c}\text { Customer trust on } \\
\text { employees }\end{array}$ & $\begin{array}{c}\text { Customer trust on } \\
\text { company }\end{array}$ & $\begin{array}{c}\text { Customer } \\
\text { loyalty }\end{array}$ \\
& Sig. (2-tailed) & 1 & & \\
\hline Customer trust on company & Pearson Correlation & $.444^{* *}$ & 1 & \\
& Sig. (2-tailed) & .000 & $87 \mid$ Page
\end{tabular}


The role of "trust" in building customer loyalty in insurance sector- $A$ study

\begin{tabular}{|c|c|c|c|c|}
\hline Customer loyalty & $\begin{array}{l}\text { Pearson Correlation } \\
\text { Sig. (2-tailed) } \\
\mathrm{N}\end{array}$ & $\begin{array}{c}.891^{* *} \\
.000 \\
285\end{array}$ & $\begin{array}{c}.460^{* *} \\
.000 \\
285\end{array}$ & $\begin{array}{r}1 \\
285\end{array}$ \\
\hline
\end{tabular}

Customer trust on company employees has been found to be significantly and positively correlated with customer loyalty $(\mathrm{r}=.891, \mathrm{p}<.01)$. The association between the two variables is above the threshold of .7 which proofs their greater association. The probability value is found to be less than .01 . Thus, Null hypothesis is rejected and alternative hypothesis is accepted. Furthermore, customer trust on company is positively and significantly correlated with customer loyalty $(\mathrm{r}=.460, \mathrm{p}<.01)$. The association between the two variables is significant but weak while the P-value is less than .01. Thus, Null hypothesis is rejected and alternative hypothesis is accepted. That means customer loyalty is higher when the customer is in trustworthy of company and employees.

As it can be seen from the above table the estimated correlation indicates that there is positive correlation among variables. The variables move in the same direction together. This means higher scores on one variable tend to be paired with higher scores on the other. The above correlation matrix table gives evidence that there is significantly and strong positive correlation between customer trust on employees and customer loyalty, but the correlation between customer trust on insurance company and customer loyalty is weak. The variables move in the same direction together. It means that, in general, higher scores on one variable tend to be paired with higher scores on the other.

\section{Respondents' responses analysis: using response scores and ANOVA.}

Insurance is highly intangible product so that the relationship between customer trust on company employees and their trust on company policies, procedures, and cultures structures need have to be known. Thus, scores are classified into: low, medium and high. Strongly disagree and disagree come under low, neither agree nor disagree come under medium and agree and strongly agree come under high. The results are depicts below.

Table 5: Customers' response of their trust on employees and companies

\begin{tabular}{|l|l|l|l|l|l|l|}
\hline \multirow{2}{*}{ Trust dimensions } & \multicolumn{2}{|l|}{ Respondents perceived trust response } & df & F & Sig \\
\cline { 2 - 5 } & Low & Medium & High & & & \\
\hline $\begin{array}{l}\text { Customer trust on Company } \\
\text { employees }\end{array}$ & $77(27 \%)$ & $23(8 \%)$ & $208(73 \%)$ & 284 & 126.12 & .000 \\
\hline $\begin{array}{l}\text { Customer trust on company } \\
\text { (policies...) }\end{array}$ & $97(34 \%)$ & $19(7 \%)$ & $169(59 \%)$ & 284 & 10.78 & .000 \\
\hline
\end{tabular}

The above table gives evidence that majority of respondents (73\%) have trust on company employees while $(27 \%)$ responses are found to be low. In addition to this $34 \%$ of respondents do not have confidence on the company, but $59 \%$ of respondents have trust on the insurance company. Customers who have trustworthiness on company employees and on the company remain loyal and in fact buy more policies from the same provider, but customers who do not have trust could shift to other providers. The F-value suggests that the relationship between customer trust and customer loyalty is significant. The P value is found to be less than .05 . Thus, null hypotheses are rejected and alternative hypotheses are accepted.

As the table above gives evidence of customer trust on company employees and customer trust on the overall companies is significant company employee's trustworthiness and their ability to convey trust and confidence can lead customers to loyalty. Furthermore, company structure, culture, policies, procedures, decision making process, etc. have roles to enhance customer loyalty. Insurance companies sell promises so that the ability to make customers trust the company and have confidence in it is a critical factor in building customer loyalty.

\section{Regression analysis}

In order to identify the effect of independent variables on customer loyalty regression analysis is employed.

\begin{tabular}{|c|c|c|c|c|c|c|}
\hline \multicolumn{7}{|c|}{ Table 6: Influence of independent variables on customer loyalty } \\
\hline & Mean & Std. Deviation & $\mathrm{R}$ & R Square & $\begin{array}{c}\text { Adjusted } \\
\mathrm{R}^{2}\end{array}$ & Sample size \\
\hline Customer loyalty & 3.693 & .7647 & \multirow{3}{*}{.894} & \multirow{3}{*}{.800} & \multirow{3}{*}{.798} & 285 \\
\hline Customer trust on employees & 3.629 & .8251 & & & & 285 \\
\hline Customer trust on company & 3.549 & .6723 & & & & 285 \\
\hline
\end{tabular}

Table 6 above, shows each variable's mean, SD, and R square. Mean scores have been computed by equally weighting the mean scores of all the items. All variable means are found to be above average. On a five-point scale, the mean scores of Customer trust on employees 3.6 indicate that the influencing power of customer trust on employees is quite high. The mean score of customer loyalty is $3.69(\mathrm{SD}=0.76)$, which suggests that 
apparently it seems that the customers are loyal to the service provider. The mean score of Customer trust on company is $3.5(\mathrm{sd}=0.67)$.

Furthermore, the table above shows the R value is .894, which represents the correlation between the observed values and predicted values of the dependent variable which indicates a high degree of correlation. The $\mathrm{R}^{2}$ value indicates how much of the dependent variable, customer loyalty, explained by the independent variables. The adjusted R square (.798) that is $79.8 \%$ of the variation in customer loyalty is explained by influencing factors, which is large.

Table 7:
\begin{tabular}{|ll|r|r|r|r|r|}
\hline Model & & SNOVA & \multicolumn{1}{c|}{ Sig. } \\
\hline 1 & Regression & 132.791 & 2 & Mean Square & F & . \\
& Residual & 33.261 & 282 & .118 & & \\
& Total & 166.053 & 284 & & & \\
\hline
\end{tabular}

a. Predictors: (Constant), Customer trust on company, Customer trust on employees

b. Dependent Variable: Customer loyalty

As it can be seen from the above table the regression row displays information about the variation accounted for the model .The regression sum of square is greater than residual sum of squares .Furthermore, the table gives evidence of $\mathrm{P}<.05$ with $\mathrm{F}$-value of 562.92 and indicates that overall, the model applied is significantly good enough in predicting the independent variables.

Findings and inferences made.

Customer trust on company employees and customer trust on the overall insurance company and customer loyalty is statistically significant, $\mathrm{F}=(562.922), \mathrm{p}<.05$. Furthermore, as shown in the table above,

$\mathrm{R}^{2}=0.800$ was obtained, and it can be said that 80 percent of the dependent variable changes is explained by the model.

Table 8: rate of change (Coefficients)

\begin{tabular}{|c|c|c|c|c|c|c|c|c|c|c|}
\hline \multirow[b]{2}{*}{ Model } & \multicolumn{2}{|c|}{$\begin{array}{l}\text { Unstandardized } \\
\text { Coefficients }\end{array}$} & \multirow{2}{*}{\begin{tabular}{|l}
$\begin{array}{l}\text { Standardized } \\
\text { Coefficients }\end{array}$ \\
Beta
\end{tabular}} & \multirow[b]{2}{*}{$\mathrm{t}$} & \multirow[b]{2}{*}{ Sig. } & \multicolumn{3}{|c|}{ Correlations } & \multicolumn{2}{|c|}{$\begin{array}{l}\text { Collinearity } \\
\text { Statistics }\end{array}$} \\
\hline & B & Std. Error & & & & $\begin{array}{l}\text { Zero- } \\
\text { order }\end{array}$ & Partial & Part & Tolerance & VIF \\
\hline 1 (Constant) & .490 & .119 & & 4.117 & .000 & & & & & \\
\hline Customer trust on employees & .793 & .028 & .856 & 28.764 & .000 & .891 & .864 & .767 & .803 & 1.245 \\
\hline Customer trust on company & .092 & .034 & .081 & 2.712 & .007 & .460 & .159 & .072 & .803 & 1.245 \\
\hline
\end{tabular}

The table above reports the coefficient of regression line, provides us with information on each IDV to predict customer loyalty from the independent variables. By looking under the Unstandardized Coefficients column we can present the regression raw equation as below:

$$
Y=.490+0.793 x_{1}+0.092 x_{2}
$$

The above equation is derived from: $\quad \mathrm{Y}=\mathrm{b}_{0} \mathrm{~b} 1 \mathrm{x} 1+\mathrm{b} 2 \mathrm{x} 2$

$\mathrm{Cul}=\mathrm{Y}=.490+0.793 \mathrm{X} 1+0.092 \mathrm{X} 2$.

Where: $y=$ dependent variable (customer loyalty

$$
\begin{aligned}
& \mathrm{b}_{0}=\text { intercept } \\
& \mathrm{b}_{1} \text { and } \mathrm{b}_{2}=\text { regression coefficient } \\
& \mathrm{X}_{1}=\text { customer trust on employees } \\
& \mathrm{X}_{2}=\text { customer trust on company } \\
& \mathrm{Cul}=\text { customer loyalty in insurance }
\end{aligned}
$$

The IDVs: customer trust on employees and customer trust on insurance company are influencing significantly customer loyalty because the probability value, 'p' is less than 0.05 . The regression analysis in table above shows that the IDV have significant impacts on customer loyalty with significance level is $<.05$, The Beta values shows us which independent variable has greater effect on DV customer loyalty i.e. one percent change in factors will entails a change in customer loyalty. The Beta coefficient shows us the effect of the independent variables on the dependent variable. Customer trust on employees (.793) has the greatest effect on customer loyalty. The more customer trust company employees the more customers go with the present providers. 
Table 9: Summarization of Regression Weight

\begin{tabular}{|lll|llll|}
\hline & & & Estimate & S.E. & C.R. \\
\hline Customer loyalty & $<---$ & Customer trust on employees & .793 & .027 & 28.866 & $* * *$ \\
Customer loyalty & $<---$ & Customer trust on insurance company & .092 & .034 & 2.722 & .006 \\
\hline
\end{tabular}

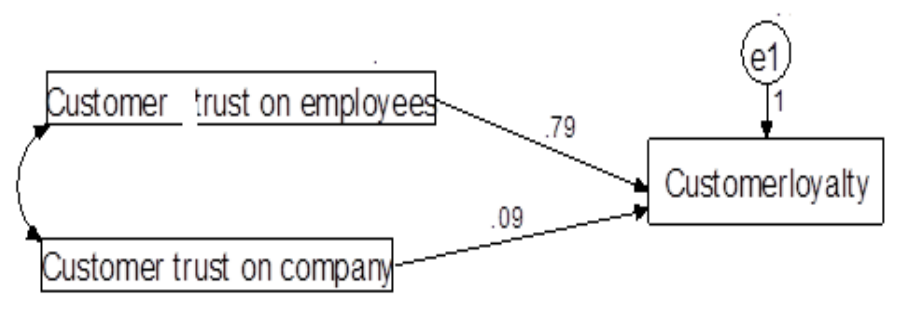

Figure 2: The influence of IDV on DV.

From the above table it is observed that:

- Estimate of regression weight - when Customer trust on employees goes up by 1, customer loyalty goes up by .793

- Standard error of regression weight- the regression weight estimates, .793, has a standard error of about .027.

- Level of significance for regression weight - the regression weight for Customer trust on employees in the prediction of customer loyalty is significantly different from zero at the .001 level (two tailed).

- Estimate of regression weight - when Customer trust on insurance company goes up by 1, customer loyalty goes up by 0.092 .

It is observed that customer trust on company employees influences customer loyalty $(\mathrm{B}=.793, \mathrm{t}=28.76$,

$\mathrm{P}<.05$. Thus, the null hypothesis is rejected and the alternative hypothesis can be accepted. When customer Trust on employees goes up by 1 , customer loyalty goes up by 0.793 . This shows an increase in trust of customers would result in an increase in loyalty to the insurance provider. If a customer is loyal to the company he/she would likely to purchase additional policies and / or tells about the company reputation to others.

However, when customers are unwilling to trust the company they are also unwilling to be loyal. When customers believe that the company is trustworthy the intention of customers to switch to other provider will be minimized.

Moreover, the importance of trust in determining customer loyalty was supported by a number of researchers. In marketing literature, Morgan and Hunt (1994) suggest that trust lead to loyalty because trust creates exchange relationship that is highly valued. Lyle (2005) examined trust, satisfaction and loyalty in CRM: an application of justice theory and he confirmed that trust and loyalty are positively related. Both customer trust in the employees and customer trust in the company are positively related to customer loyalty ( Sirdeshmukh \& et al., 2002). Mei-Fang Chen \& Liang-Hung Mau (2009) research result shows that customer trust in the life insurance company make positive contribution to customer loyalty. Customer trust has a positive influence on customer loyalty. The greater the customer trust is, the higher the customer loyalty becomes (Kennedy et al., 2001; Sirdeshmukh et al., 2002).

\section{Conclusions}

The problem of customer lapsing in Ethiopian insurance sector which could lead for the decline of premium \& low insurance penetration initiated this study to be launched. Hence, the study was designed to examine the influence of customer trust on employees and customer trust on insurance company towards customer loyalty in insurance sector of Ethiopia.

The findings of the study shows that customer trust on employees and customer trust on insurance company play a vital role in influencing customers towards loyalty in insurance sector of Ethiopia. Customer trust on company employees and customer loyalty are strongly and positively correlated( $\mathrm{r}=.891)$. Furthermore, customer trust on insurance company is also positively correlated, but the strength of correlation is weak $(\mathrm{r}=.460)$. The effect of influencing variables on customer loyalty is also significant at .05 level two tailed. Estimate of regression weight shows when customer trust on company employees goes up by 1 , customer loyalty goes up by 0.793 . When customer trust on insurance company goes up by 1 , customer loyalty goes up by .092. This shows a change in customer trust leads to a change in customer loyalty.

In nutshell, as the result shows customer trust is an important antecedent of customer loyalty. Thus, insurers need to focus on the construct of trust which contains belief in the company employees and insurance company as a whole, which provide to customers an assurance of positive outcomes not only for the present but also for the future. As illustrated in the literature, customers must be to believe that the company will not behave opportunistically for sake of its own interest; otherwise they will switch to other providers. The greater 
customers develop trust on company employees and on the overall company the higher will be their loyalty to the present insurance providers which in turn become means of prosperity.

\section{Bibliography}

[1]. Brown, J.T., \& Chen.S., (2001). The Relationship between Customer Loyalty \& Customer Satisfaction. International Journal of contemporary Hospitality Management, Vol, 13 no. 5 pp213-217.

[2]. Chris Halliburton and Adina poenaru.(2010). The Role of Trust in Consumer Relationships: ESCP Europe Business School.

[3]. Christine Moorman, Rohit Deshpande, \& Gerald Zaltman (1993, January 2).Factors Affecting Trust on Market Research Relationships. Journal of Marketing, 57 (), 81-101.

[4]. Coulter and Coulter, (2003), "The effects of industry knowledge on the development of trust in

[5]. Service relationships", International Journal of Research in Marketing 20 (2003) 31-43.

[6]. Dwyer, F., Robert, Paul H., Schurr, and Sejo, O., (1987) . Developing buyer-seller relationships. Journal of Marketing, 51, April, 11-27.

[7]. Ernst \& young (2012). Global Consumer Insurance Survey, America. Retrieved from http://www.ey.com/GL/en/Industries/Financial-Services/Insurance

[8]. Ernst \& Young (2012). Asia -Pasific Global consumer survey. Retrieved from www.ey.com/insurance

[9]. Ernst \& Young (2012). Global Insurance Customer Study (Voice of the customer). Retrieved from : http://www.ey.com/Publication/vwLUAssets/Global_Consumer_Insurance

[10]. Ethio-life Insurance S.C. (2010/11, October 2011). Annual Report. Addis Ababa.

[11]. Ethiopian Insurance Corporation. (2010/11). Annual Report. Addis Ababa.

[12]. Ganesan, S., (1994). Determinants of Long-term Orientation in Buyer-Seller Relationships. Journal of Marketing, 58(2), 1-19.

[13]. Gefen, D., Straub, D. W., (2003). Managing user trust in B2C e-services, E - Service. Journal, Bloomington, Vol. 2, no. 2, pp. 7.

[14]. Genesy, A., Alcatel, L. , (2008). Customer service strategy for the insurance industry. Industry strategy guide. P. 8

[15]. Goodman, N ., (2012). Ways to Build Consumer Trust. Available at: http://www.entrepreneur.com/blog/224622

[16]. Gronroos, C.,(2001).Service Management and Marketing: A Customer Relationship Management Approach. Chichester, UK. John Wiley.

[17]. Guillen M, Parner J, Densgsoe C., \& Ana, M., (2002). Customer loyalty in insurance industry. University of Barcelona , Spa in.

[18]. Halliburton,C., \& Poenaru A., (2010).The role of trust on consumer relationship. ESCP Europe Business school.

[19]. Hailu Zeleke (2007). Insurance in Ethiopia, present status and future challenges, Addis Ababa, Masters printing press.

[20]. Halliburton C.,and Poenaru , A., (2010). The role of trust in consumer relationship. ESCP Europe Business School, UK.

[21]. Heskett, J., Jones, T., Loveman, G.W and Schlesinger L.A., (March-April ,1994). Putting the service profit chain to work, Harvard Business review. 164.

[22]. Hinkle, wiersma, and Jurs (2003). Applied Statistics for the Behavioral Science, 5th ed.

[23]. .Insurance Technology - CRM in Global Insurance (2008). Data monitor.

[24]. Jacada (2008). Insurance providers, improving customer retention. Insurance Technology - CRM in Global Insurance, Datamonitor,

[25]. Kennedy, M.S., Ferrell, L.K., and Leclair, D.T., (2001). Consumers' trust of salesperson and manufacturer: An empirical study. Journal of Business Research 51(1), 73-86.

[26]. Kothari C.R., (2011). Research Methodology Methods \& techniques. New age international (p) Limited, publishers, New Delhi ,2nd edn.

[27]. Lovelock, C, and Wirtz, J., (2004). Service marketing: people, Technology \& strategy Person ,Education International.

[28]. Mei-Fang Chen \& Liang-Hung Mau (2009). The impacts of ethical sales behavior on customer loyalty in the life insurance industry. The Service Industries Journal, 29:1,59-74 http://www.tandfonline.com/loi/fsij20

[29]. Mei-Fang C., \& Ling-Huei , W., (2009). The moderating role of switching barriers on customer loyalty in the life insurance industry. The Service Industries Journal, 29:8, 1105-1123. Viewed at :http://dx.doi.org/10.1080/02642060902764574

[30]. Morgan, RM. and Hunt, S.D., ( 1994). The Commitment- Trust Theory of Relationship Marketing. Journal of Marketing, Vol, 58, pp.20-38.

[31]. Nana, Wei (2010). Investigating factors that can have an impact on customer loyalty -an empirical study of IKEA. University of Gävle Department of Business Administration.

[32]. Nargundkar R. (2010). Marketing research Text \& cases, Tata McGraw Hill Education Private Limited, New Delhi, 3rd edn.

[33]. Negi , D., Singh, P., (2012). Demographic Analysis of Factors Influencing Purchase of Life

[34]. Insurance Products in India. European Journal of Business and Management. (2012), Vol 4, No.7. Available at: www.iiste.org

[35]. Nile Insurance S.C. (2010/11,30 June).Board of directors annual report. Addis Ababa.

[36]. Nyala Insurance S.C.(2010/11, November 2011).Board of directors annual report. Addis Ababa

[37]. Oromia Insurance S.C.(2010/11, November 2011).Board of directors annual report. Addis Ababa

[38]. Prabhakar Kasands (June, 2006). Customer relationship in Business schools. Nice Journal of Business, 11th edn, vol.1 .no.1.Presentation Web: Available at: http://www.preventionweb.net/english/countries/statistics/?cid=59.Retrieved at 12 October 2012

[39]. Psarou M. K. \& Zafiropoulos, C. (2004). Scientific Research: Theory and Applications in Social Sciences, Athens, Tipothito, Dard

[40]. Rechheld, F.F (1993). Loyalty-based management, Harvard business review, March-April, 64-73

[41]. Reichheld, Frederick, (1996). The loyalty effect - The hidden force behind growth, Profits,and lasting value, Boston, Mass.: Harvard Business School Press. Retrieved from http://businessoverbroadway.com )

[42]. Reichheld, F. F., (2003). The One Number You Need to Grow. Harward Business Review, Vol. 81, Issue 12, pp. 46-55.

[43]. Roger, et al., (2011). Customer relationship management. Printed in India. Akash press.

[44]. Sirdeshmukh, D, Singh, J, and Sabol, B., ( 2002). Consumer trust, value, and loyalty in relational exchanges. Journal of Marketing, 66(1), 15-37.

[45]. Spekman, R., (1998). Strategic supplier selection, understand long-term buyer relationship, Bus, Horiz., 75. Vol. 9, pp. 53-55.

[46]. Yousafzai et al.,( 2005). Strategies for Building and Communicating Trust in Electronic Banking: A Field Experiment. Psychology and Marketing, Vol. 22, No. 2, pp. 181-20

[47]. Zikmund. G. McLeod,J. Gilbert F.,(2003). CRM, Integrating Marketing strategy and IT . Replika Press pvt.Ltd, India, . 
Respondents profile (using relative frequencies)

\section{Appendix}

In this section an attempt has been made to present research sample participant profiles. This demographic characteristic is helpful for further analysis to know whether there is relation between demographic factors and customer loyalty exists. If relationships exist insurers will have possibility to deploy resources for working on demographic factors. The selected demographic variables selected for this study are: sex, marital status, respondents' age, income, education level, family size, and respondents waiting time in the company which are depicted below.

\begin{tabular}{|lll|}
\hline Table 1: Respondents sex distribution & \\
\hline & No. of Respondents & Percent \\
Female & 79 & 27.7 \\
Male & 206 & 72.3 \\
Total & 285 & 100 \\
\hline
\end{tabular}

As it is seen in table above table the respondents had a relatively a major portion of males $(72.3 \%)$ as compared to female (27.7\%). The proportion of males and females is in accordance with the present participation in public and private insurance companies in Ethiopia and, therefore it can be said that the ratio of males is very high as compared to females.

\begin{tabular}{|l|l|l|}
\hline Table 2: Respondents age distribution & percent \\
\hline Age & No. of Respondents & 2.8 \\
\hline Below 25 years & 8 & 41.8 \\
\hline $25--44$ & 119 & 45.3 \\
\hline $45--64$ & 129 & 10.2 \\
\hline 65 or above & 29 & 100 \\
\hline Total & 285 & \\
\hline
\end{tabular}

The above table also shows that sample customers were mostly in the age group of 45-64, 129 (45\%).It is also evident from the table that $41.8 \%$ of the respondents were $(25-44)$, and $2.8 \%$ were below the age of 25 years

\begin{tabular}{|lll|}
\hline Table 3: & Respondents marital status & \\
& No. of Respondents & percent \\
Single & 11 & 3.9 \\
Married & 219 & 76.8 \\
Others & 55 & 19.3 \\
Total & 285 & 100 \\
\hline
\end{tabular}

The above table shows the majority of the respondents were married $(76.8 \%)$ while percentage of single (unmarried) respondents were (3.9\%)while the group in others as separated, divorced and widow have a percentage of $(19.3 \%)$. The table shows that more respondents were from married class.

\begin{tabular}{|lll|}
\hline Table 4: Respondents occupational status & percent \\
& No. of Respondents & 42.5 \\
Business class & 121 & 46.3 \\
Salary class & 132 & 11.2 \\
Others & 32 & 100 \\
Total & 285 & \\
\hline
\end{tabular}

The above table shows that most of the respondents (46.3\%) are from salary group ; work in government or in private owned organizations while (42.5\%) are from business group. In others group are those who are; house wife, students, unemployed \& others comprises (11.2\%).

\begin{tabular}{|lll}
\hline Table 5: Respondents Educational level & No. of Respondents & percent \\
High school or less & 134 & 47 \\
Undergraduate & 99 & 34.7 \\
Postgraduate or above & 52 & 18.2 \\
Total & 285 & 100 \\
\hline
\end{tabular}

The above table shows that the respondents were predominantly high school or less $(47 \%)$ and undergraduates $(34.7 \%)$. And the least (18.2\%) are elite people. 


\begin{tabular}{|c|c|c|}
\hline Income in Birr & No. of Respondents & percent \\
\hline 5000 or less & 22 & 7.7 \\
\hline $5001-10,000$ & 145 & 50.9 \\
\hline $10,001-15,000$ & 90 & 31.6 \\
\hline 15001 or above & 28 & 9.8 \\
\hline Total & 285 & 100 \\
\hline
\end{tabular}

The above table indicates the study had a majority of the respondent earning Birr 5001-10,000 (50.9\%) followed by monthly income of 10,001-15,000 (31.6\%) and income of 15001-and above (9.8\%).People whose income are below 5001 are very few $(7.7 \%)$ in the participation.

\begin{tabular}{|lll|}
\hline Table 7: Respondents Family size & percent \\
1-2 families & No. of Respondents & 12.3 \\
3-5 families & 35 & 32.3 \\
6-8 families & 92 & 34.4 \\
9 or more & 98 & 21.1 \\
Total & 60 & 100 \\
\hline
\end{tabular}

Most of the respondent's family sizes are observed (6-8) 34.4\%.Participants that have below 5 members comprises $45 \%$ of all the respondents. These shows Ethiopian live in the conventional nuclear family as compared to dominated extended family in the Indian society. Most of the families are nuclear family.

\begin{tabular}{|lll|}
\hline Table 8: Respondents staying time in the company & & \\
Staying years & No. Respondents & percent \\
Two years or less & 111 & 38.9 \\
3-5 years & 107 & 37.5 \\
Six years or more & 67 & 23.5 \\
Total & 285 & 100 \\
\hline
\end{tabular}

Most of the respondents (38.9\%) have experience of two years or less got service in the present insurance company. Those who have who got service three to five years are $37.5 \%$ and who stayed with the present company are $23.5 \%$.

Table 9: Factors attracted customers for purchasing policies

\begin{tabular}{|l|c|r|}
\hline & Frequency & \multicolumn{1}{|r|}{ Percent } \\
\hline Friends, relatives, etc. & 94 & 33.0 \\
Advertisement & 71 & 24.9 \\
Government/cooperative advice & 70 & 24.6 \\
others & 50 & 17.5 \\
Total & 285 & 100.0 \\
\hline
\end{tabular}

As the above table reported the majority of respondents (33\%) were attracted to purchase their first insurance policies by advice of their friends, relatives and acquaintance. This result coincides with Ernst \& Young (2012) Global insurance survey result which reveals that $52 \%$ of the respondents confirmed they consulted friends, relatives' acquaintances for purchasing new insurance policy. These people (the consultant) have prior experience of insurance or have good image for the reputation of the company in playing advocacy for the company. Thus, insurance companies should have to improve their overall services to attract new customers. 